\title{
Investigation and Analysis of ICT development index (IDI) for measuring ICT resources in Georgia
}

\author{
Giorgi Popkhadze ${ }^{1}$, Predrag Dašić ${ }^{2,3}$, Raul Turmanidze ${ }^{1}$ \\ ${ }^{1}$ Georgian Technical University (GTU), Faculty of Transportation and Mechanical Engineering, \\ Tbilisi - Georgia \\ ${ }^{2}$ Academy of Professional Studies Šumadija - Department in Trstenik, Trstenik - Serbia \\ ${ }^{3}$ SaTCIP Publisher Ltd., Vrnjačka Banja - Serbia
}

\begin{abstract}
Information and communication technologies (ICT) are a set of equipment (devices, systems, etc.) and techniques with associated software (software systems and software tools) that have been developed and used for more efficient communication, creation, distribution, storage and management of information. The IDI (ICT Development Index) index is most often used to measure ICT resources, which is defined as a composite index that combines 11 indicators (classified into 3 sub-indices: Access, Use and Skills). Data on values of IDI index has been retrieved from Measuring the Information Society Report (MISR), which since 2008 has been publishing by International Telecommunications Union (ITU). The IDI index for 2017 was determined for 176 countries of the world, with the first on the ranking list was Iceland with $I D I_{2017}=8.98$ and the last Eritrea with $I D I_{2017}=0.96$. The mean value of IDI index for 2017 was $A v g=5.11$, standard deviation was $S t D=2.22$ and coefficient of variation was CoV=43.52. In this paper is given of analysis of IDI (ICT development index) for measuring ICT resources in Georgia. The data were approximated using a 3rd degree polynomial regression model (PRM3) with a correlation coefficient $R=0.9964$, determination coefficient $R^{2}=0.9928$ and adjustment coefficient of determination is $\mathrm{Adj} R^{2}=0.9885$.

Keywords: Information technology (IT), Information and communication technologies (ICT), ICT development index (IDI), Industry 4.0
\end{abstract}

\section{Introduction}

Information and communication technologies (ICT) are technologies (hardware and software or resources and tools) that have been developed and used for more efficient communication, creation, distribution, storage and management of information. They represent a set of equipment (devices, systems, etc.) and techniques with associated software, which include complete computer and communication technologies $[4-5,9,11,14,16]$.Information and Communication Technologies (ICTs) is an extensional term for Information Technology (IT), which refers to all communication technologies and that stresses the role of unified communications and the integration of telecommunications (telephone lines and wireless signals) and computers and information processing. By these we mean computer and communication devices and systems, such as: Internet, wireless networks, cell phones, mobile phones, smart phones, computers (super computers, mini computers, personal computers, desktops and laptops computers, tablets and etc.), robots, digital cameras, software, middleware, video-conferencing, social networking, and other media, applications and services enabling users to access, retrieve, store, transmit and manipulate information in a digital form.

In recent decades, there has been an astonishingly rapid development of ICT technologies thanks to cheap micro and nano electronics and micro and nano materials that have enabled the spread of ICT technologies in almost all spheres of society and in almost all aspects of everyday life. ICTs are of fundamental importance to modern society, enabling as much transfer of the most diverse amounts of information as has ever been possible before in the history of mankind. For seventy years of development, such progress has been recorded as mechanical engineering, architecture, construction and similar classical technical disciplines have achieved during 2 to 3 centuries of development [5].

Within the International Organization for Standardization (ISO), the areas of ICT are classified according to the International Classification for Standards (ICS) in the group of international standards 33 (Telecommunications: Audio and video engineering) and 35 (Information technology). 
It should also be noted that the field of information technology (IT) $(\mathrm{ICS}=35)$ has the highest number of adopted international standards [5].

The development trend of ICT technologies is presented in the papers [9-10, 14-15, 22]. 25-26].

ICT represents key technologies in a new manufacturing philosophy called Industry $4.0[5,13$,

\section{ICT development index (IDI)}

The ICT development index (IDI) is a composite index that combines 11 indicators (classified into 3 sub-indices: Access, Use and Skills) into one benchmark measure that can be used to monitor and compare developments in information and communication technology (ICT) between countries and over time [1-3, 8, 12, 20-21]. The ICT development index (IDI) ranks and compares the level of ICT technologies use and access across the various countries around the world. This makes it a valuable tool for benchmarking the most important indicators for measuring the information society. The IDI is a standard tool that governments, operators, development agencies, researchers and others can use to measure the digital divide and compare ICT performance within and across countries.

The IDI index ranges from 0 (the country with the lowest percentage of ICT technologies use) to 10 (the country with the highest percentage of ICT technologies use).

The IDI index was formerly known as the Digital Opportunity Index (DOI).

The IDI index was developed and published by ITU (International Telecommunications Union) in 2008 in response to requests from ITU Member States to develop an overall ICT index, was first presented in the 2009 edition of the Measuring the Information Society Report (MISR) [17-20], and has been published annually since then.

\section{Materials and methods}

Data on values of IDI index for Georgia has been retrieved from Measuring the Information Society Report (MISR) [12-13] for period 2007-2017 [17-20], with a certain calculations from the part of the authors.

For the trend analysis, we used the following parameters: Annual Growth (AG), Annual Growth Rate (AGR) and Compound Annual Growth Rate (CAGR), described in the papers [6-7, 23-27].

For the calculation of descriptive statistics parameters and determination of a polynomial regression model (PRM) we used software package CoPRMTV and software system MS-Excel.

\section{Results and discussion}

In 2014 ITU released the latest rankings of the IDI index, with Iceland (IDI=8.98) attaining the top spot, followed by South Korea (IDI=8.85), next Switzerland (IDI=8.74) and etc. (Fig. 1). The top 30 countries in the rankings include most high-income countries where the quality of life is higher than average, which includes countries from Europe and other regions such as "Australia, Bahrain, Canada, Japan, Macao (China), New Zealand, Singapore, and the USA". Almost all of these countries have improved their IDI rankings this year compared to 2016.

On Table 1 are given data about IDI index of Gergia for the period 2007-2017 [17-20], with calculation by the authors for: position [\%], quartile (Q) and compound annual growth rate (CAGR).

Fig. 2 shows the trend of the IDI index in the Georgia for the period 2007-2017.

Fig. 3 shows the values of the compound annual growth rate (CAGR) in the Georgia for the period 2008-2017. 


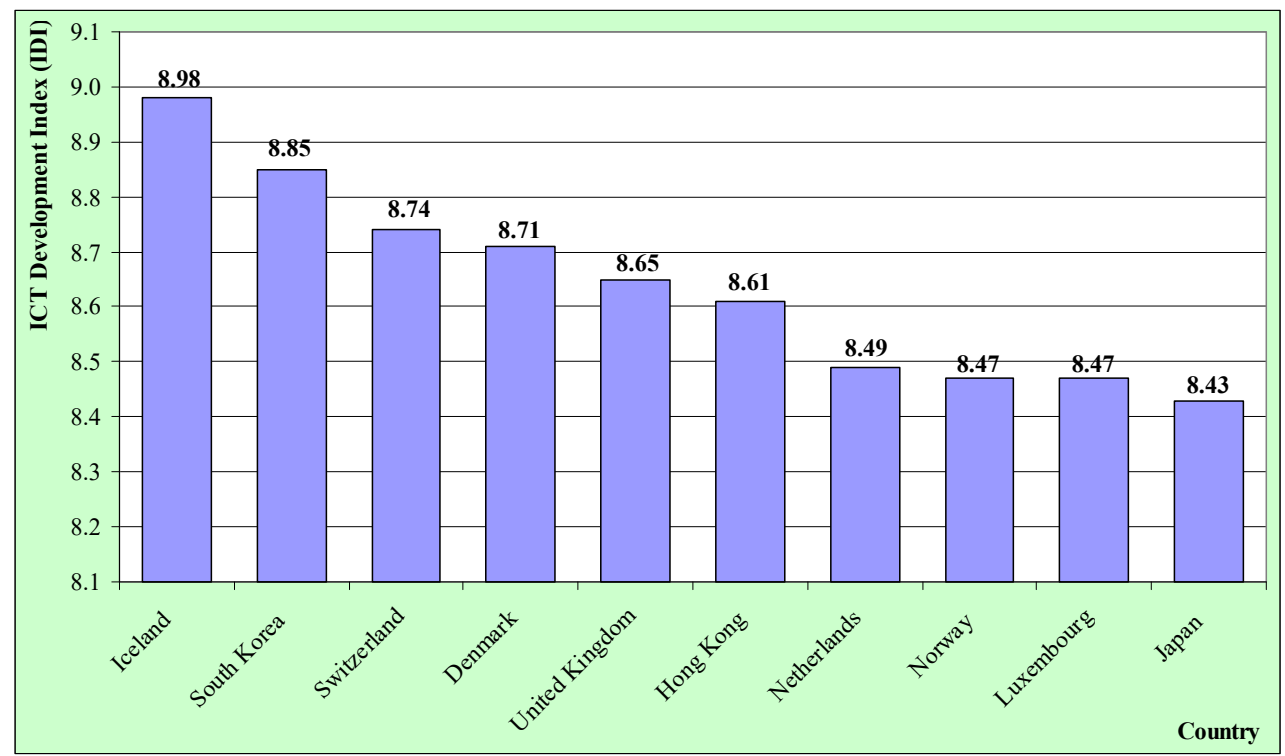

Fig. 1. Graphic representation of the top 10 countries on the ranking list by IDI index for 2017

Table 1: Data about ICT development index (IDI) of Gergia for the period 2007-2017

\begin{tabular}{|c|c|c|c|c|c|}
\hline Year & Score & Rank & Position [\%] & Q & CAGR [\%] \\
\hline 2007 & 2.91 & $80 / 154$ & 51.95 & Q3 & - \\
\hline 2008 & 2.96 & $85 / 154$ & 55.19 & Q3 & 1.72 \\
\hline 2010 & 3.76 & $85 / 166$ & 51.20 & Q3 & 12.71 \\
\hline 2011 & 4.24 & $73 / 157$ & 46.50 & Q2 & 12.77 \\
\hline 2012 & 4.48 & $83 / 166$ & 50.00 & Q2 & 5.66 \\
\hline 2013 & 4.86 & $78 / 166$ & 46.99 & Q2 & 8.48 \\
\hline 2015 & 5.25 & $78 / 167$ & 46.71 & Q2 & 3.93 \\
\hline 2016 & 5.59 & $73 / 176$ & 41.48 & Q2 & 6.48 \\
\hline 2017 & 5.79 & $74 / 176$ & 42.05 & Q2 & 3.58 \\
\hline
\end{tabular}

The IDI index for Georgia has been growing steadily during this period, and highest growth of CAGR rate was by 12.71 in 2010 and 12.77 in 2011 (Table 1 and Fig. 3). Georgia had a constant growth trend in the IDI index and was always in the Q2 and Q3 quarters (Table 1).

Data about IDI index of Gergia for the period 2007-2017 can be approximated by a 3rd degree polynomial regression model (PRM3) (Fig. 4):

IDI $=13748965.15-20517.02 \cdot y+10.2054 \cdot y^{2}-0.00169 \cdot y^{3}$

with a coefficient of correlation $\mathrm{R}=0.9964$, coefficient of determination $\mathrm{R}^{2}=0.9928$ and adjustment coefficient of determination is $\mathrm{Adj}^{2}=0.9885$.

Georgia with 14 other countries make up one of the 15 sovereign states, which were federal republics of the USSR, now called the Post-Soviet States (PSS), also known as the former Soviet Union (FSU). The commonwealth of independent states (CIS) consists of 10 former Soviet Republics that differ in their membership status. At present the CIS unites: Armenia, Azerbaijan, Belarus, Georgia, Kazakhstan, Kyrgyzstan, Moldova, Russia, Tajikistan, Turkmenistan, Ukraine and Uzbekistan.

The values of the IDI index, as well as the ranking in world and the ranking in post-Soviet states (PSS) in 2017, for PSS countries are shown in Table 2 and graphically in Fig. 5. 


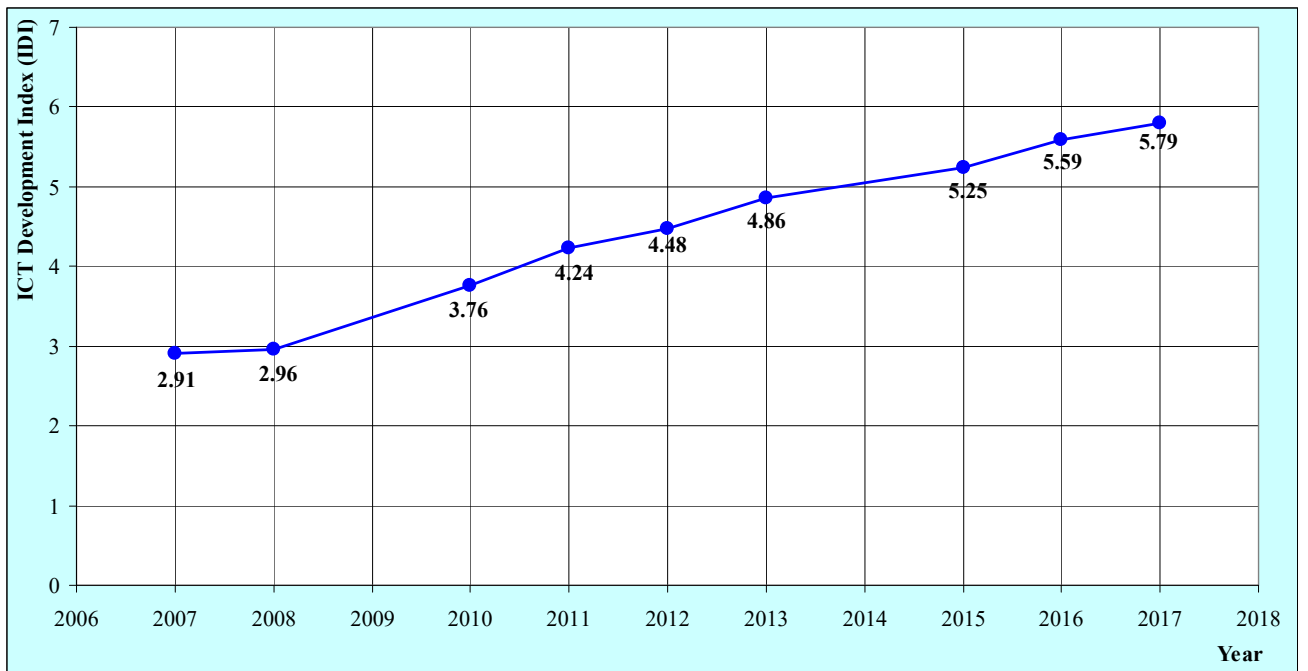

Fig. 2: Trend of the ICT development index (IDI) in the Georgia for the period 2007-2017

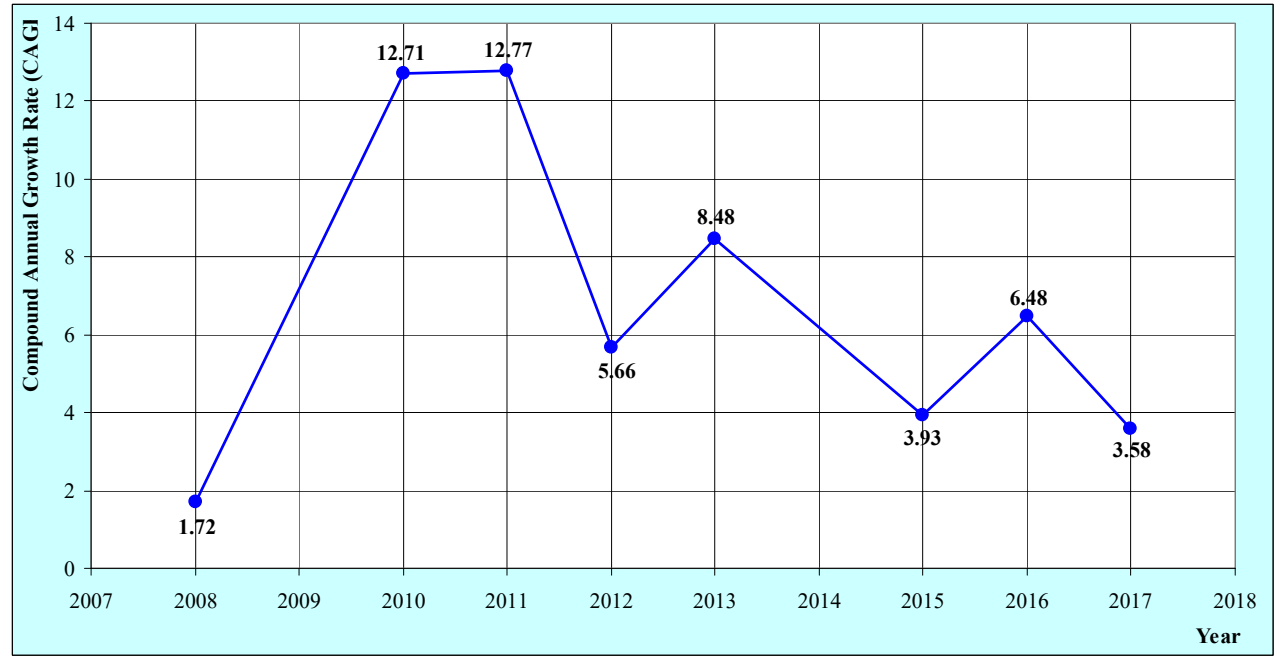

Fig. 3: Values of the compound annual growth rate (CAGR) in the Georgia for the period 2008-2017

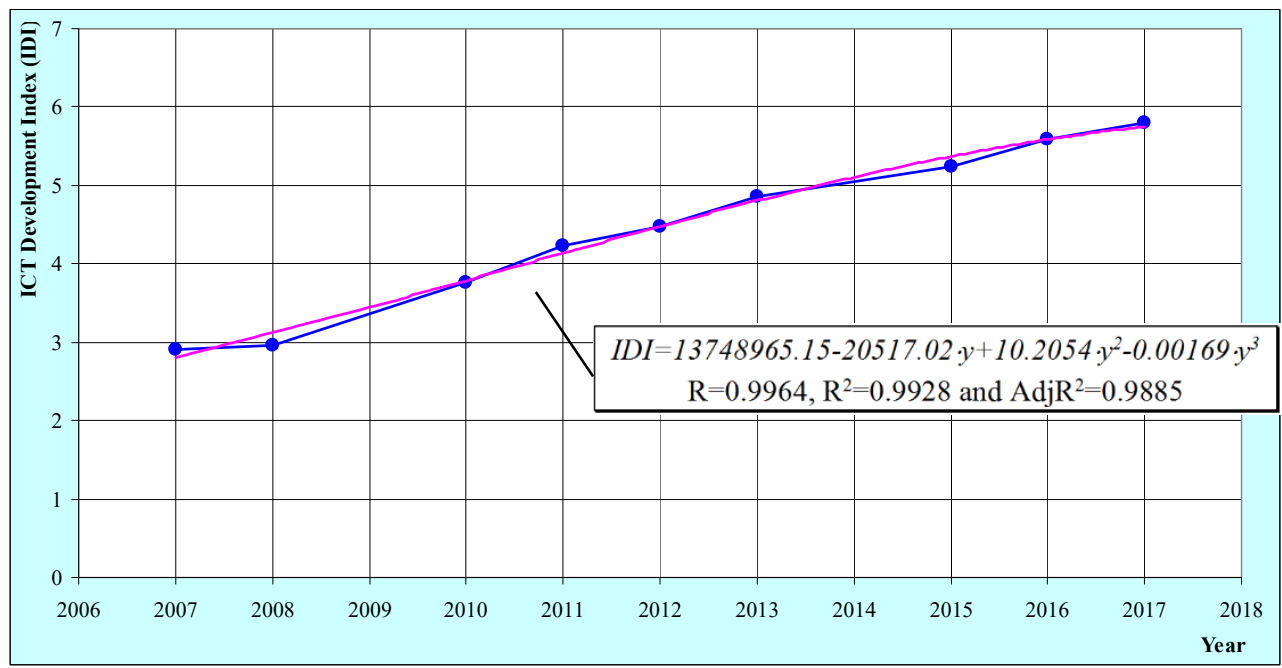

Fig. 4: Graphical representation of data of IDI index and prediction value of PRM3 
Georgia with 14 other countries make up one of the 15 sovereign states, which were federal republics of the USSR, now called the Post-Soviet States (PSS), also known as the former Soviet Union (FSU). The commonwealth of independent states (CIS) consists of 10 former Soviet Republics that differ in their membership status. At present the CIS unites: Armenia, Azerbaijan, Belarus, Georgia, Kazakhstan, Kyrgyzstan, Moldova, Russia, Tajikistan, Turkmenistan, Ukraine and Uzbekistan.

The values of the IDI index, as well as the ranking in world and the ranking in post-Soviet states (PSS) in 2017, for PSS countries are shown in Table 2 and graphically in Fig. 5.

Table 2. Values for ICT development index (IDI) for post-Soviet states (PSS) in 2017

\begin{tabular}{|l|c|c|c|c|c|c|c|}
\hline \multicolumn{1}{|c|}{ Country } & $\begin{array}{c}\text { Capital } \\
\text { city }\end{array}$ & $\begin{array}{c}\text { Population } \\
\text { (approx. in 2020) }\end{array}$ & Score & $\begin{array}{c}\text { Rank } \\
\text { in World }\end{array}$ & $\begin{array}{c}\text { Position } \\
{[\%]}\end{array}$ & Quarter & $\begin{array}{c}\text { Rank } \\
\text { in PSS }\end{array}$ \\
\hline Armenia & Yerevan & 2.967 .000 & 5.76 & $75 / 176$ & 42.61 & Q2 & $10 / 15$ \\
\hline Azerbaijan & Baku & 8.238 .700 & 6.20 & $65 / 176$ & 36.93 & Q2 & $8 / 15$ \\
\hline Belarus & Minsk & 9.648 .500 & 7.55 & $32 / 176$ & 18.18 & Q1 & $2 / 15$ \\
\hline Estonia & Tallinn & 1.299 .400 & 8.14 & $17 / 176$ & 9.66 & Q1 & $1 / 15$ \\
\hline Georgia & Tbilisi & 4.615 .800 & 5.79 & $74 / 176$ & 42.05 & Q2 & $9 / 15$ \\
\hline Kazakhstan & Astana & 15.399 .400 & 6.79 & $52 / 176$ & 29.55 & Q2 & $6 / 15$ \\
\hline Kyrgyzstan & Bishkek & 5.431 .700 & 4.37 & $109 / 176$ & 61.93 & Q3 & $13 / 15$ \\
\hline Latvia & Riga & 2.231 .500 & 7.26 & $35 / 176$ & 19.89 & Q1 & $3 / 15$ \\
\hline Lithuania & Vilnius & 3.555 .200 & 7.19 & $41 / 176$ & 23.30 & Q1 & $4 / 15$ \\
\hline Moldova & Chişinău & 4.320 .700 & 6.45 & $59 / 176$ & 33.52 & Q2 & $7 / 15$ \\
\hline Russia & Moscow & 140.041 .200 & 7.07 & $45 / 176$ & 25.57 & Q2 & $5 / 15$ \\
\hline Tajikistan & Dushanbe & 7.349 .100 & - & - & - & - & - \\
\hline Turkmenistan & Ashgabat & 4.884 .900 & - & - & - & - & - \\
\hline Ukraine & Kiev & 45.700 .400 & 5.62 & $79 / 176$ & 44.89 & Q2 & $11 / 15$ \\
\hline Uzbekistan & Tashkent & 27.606 .000 & 4.90 & $95 / 176$ & 53.98 & Q3 & $12 / 15$ \\
\hline
\end{tabular}

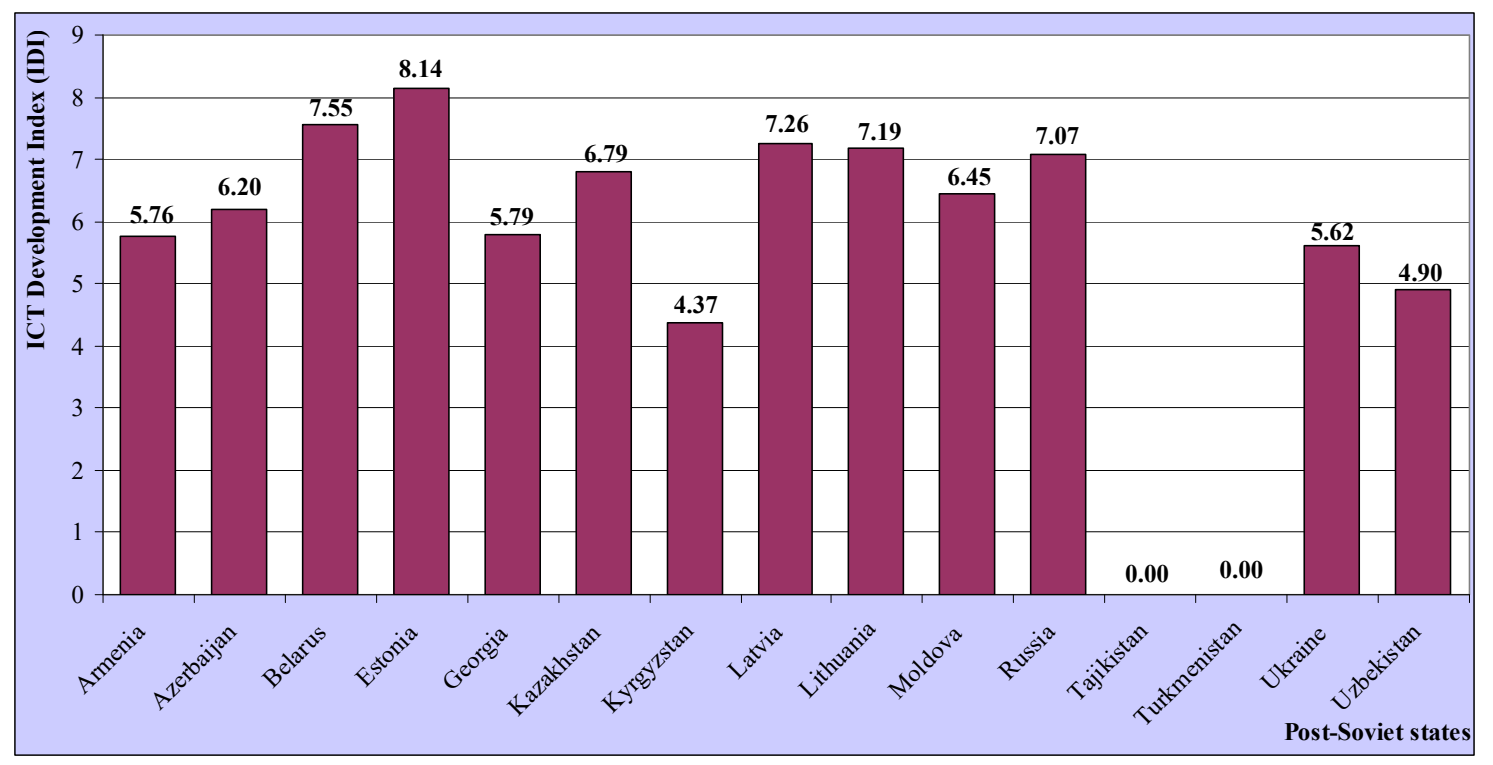

Fig. 5. Graphic representation of values for ICT development index (IDI) for post-soviet countries in 2017

\section{Conclusion}

The IDI index for 2017 is determined for 176 countries of the world, according to the International Telecommunications Union (ITU). The maximum value of the IDI index for 2017 was 
$\max =8.98$ (Iceland), minimum value was $\min =0.96$ (Eritrea), the mean value was $A v g=5.11$, standard deviation was $\mathrm{StD}=2.22$ and coefficient of variation was $\mathrm{CoV}=43.52$.

Data about IDI index of Gergia for the period 2007-2017 can be approximated by a 3rd degree polynomial regression model (PRM3), with a coefficient of correlation $\mathrm{R}=0.9964$, coefficient of determination $\mathrm{R}^{2}=0.9928$ and adjustment coefficient of determination is $\operatorname{Adj} \mathrm{R}^{2}=0.9885$.

From 15 post-soviet countries (PSS) in 2017, they take the leading place: Estonia ( $\mathrm{IDI}_{2017}=8.14$ ), Belarus ( IDI $\left._{2017}=7.55\right)$, Latvia (IDI $\left.2017=7.26\right)$ and etc.

\section{Acknowledgment}

This work was supported by Shota Rustaveli National Science Foundation (SRNSF) [PHDF-192224, Improving the efficiency of mechatronic systems in order to ensure the reform of "Industry-4.0"].

\section{References}

1. Afshar Ali, M.; Alam, K. \& Taylor, B.: Incorporating affordability, efficiency, and quality in the ICT development index: Implications for index building and ICT policymaking. The Information Society, Vol. 36, Issue 2 (2020), pp. 71-96. ISSN 0197-2243. doi: 10.1080/01972243.2019.1702601.

2. Ayanso, A.; Cho, D.I. \& Lertwachara, K.: ICT development index and the digital divide. In: Proceedings of the International Conference on Information Resources Management (ConfIRM-2011); Seoul, South Korea; 12-14 June 2011. Red Hook (New York - USA): Curran Associates Inc., 2013, pp. 943- 952. ISBN 978-1-62276-624-6.

3. Bahnamiri, M.V.; Khademabbasi, S. \& Valinataj, M.: A multi-criteria decision method using fuzzy TOPSIS technique for ranking countries based on ICT development index (IDI). International Journal of Applied Business and Economic Research, Vol. 13, Issue 6 (2015), pp. 3851-3869. ISSN 0972-7302.

4. Chen, S.-P.: Fundamentals of information and communication technologies. Newcastle upon Tyne (United Kingdom): Cambridge Scholars Publishing, 2020. - 238 pp. ISBN 978-1-5275-5585-3.

5. Dašić, P.: Scientific and technological trends: Selected scientific-professional papers (in Serbian). Vrnjačka Banja: SaTCIP Publesher Ltd., 2020. - 305 str. ISBN 978-86-6075-072-5.

6. Dašić, P.: Statistical analysis and modeling of global competitiveness index (GCI) of Serbia. Journal of Research and Development in Mechanical Industry (JRaDMI), Vol. 10, Issue 4 (2018). ISSN 1821-3103.

7. Dašić, P.; Dašić, J.; Antanasković, D. \& Pavićević, N.: Statistical analysis and modeling of global innovation index (GII) of Serbia. Lecture Notes in Networks and Systems (LNNS), Vol. 128 (2020), pp. 515-521. ISSN 2367-3370 and ISBN 978-3-030-46816-3. doi: 10.1007/978-3-03046817-0_59.

8. Dobrota, M.; Jeremic, V. \& Markovic, A.: A new perspective on the ICT development index. Information Development, Vol. 28, Issue 4 (November 2012), pp. 271-280. ISSN 0266-6669. doi: $10.1177 / 0266666912446497$.

9. Dutton, W.H. \& Peltu, M. (editors): Information and communication technologies: Visions and realities. New York (New York - USA): Oxford University Press Inc. (OUP), 1996. - 484 pp. ISBN 978-0-19-877496-9.

10. Farhadi, M.; Ismail, R. \& Fooladi, M.: Information and communication technology use and economic growth. PLoS One, Vol. 7, Issue 11 (November 2012), Article no. e48903: pp. 1-7. eISSN 1932-6203. doi: 10.1371/journal.pone.0048903.

11. Feridun, M. \& Karagiannis, S.: Growth effects of information and communication technologies: Empirical evidence from the enlarged EU. Transformations in Business and Economics, Vol. 8, Issue 2 (September 2009), pp. 86-99. ISSN 1648-4460. 
12. James, J.: The ICT Development Index and the digital divide: How are they related? Technological Forecasting and Social Change, Vol. 79, Issue 3 (March 2012), pp. 587-594. ISSN 00401625. doi: 10.1016/j.techfore.2011.08.010.

13. Karabegović, I.; Kovačević, A.; Banjanović-Mehmedović, L. \& Dašić, P. (editors): Handbook of research on integrating Industry 4.0 in business and manufacturing. Hershey (Pennsylvania USA): IGI Global, 2020. - 400 pp. ISBN 978-1-7998-2725-2. doi: 10.4018/978-1-7998-2725-2.

14. Khakimov, A.; Karlinskiy, V.\& Rakhmatullin, R.: Information and communication technologies in SMEs: Competitiveness analysis. Journal of Entrepreneurship Education, Vol. 21, Special Issue 2 (2018), pp. 1-9. ISSN 1098-8394.

15. Latif, Z.; Xin, W.; Khan, D.; Iqbal, K.; Pathan, Z.H.; Salam, S. \& Jan, N.: ICT and sustainable development in South Asian countries. Human Systems Management (HSM), Vol. 36, Issue 4 (November 2017), pp. 353-362. ISSN 0167-2533. doi: 10.3233/HSM-17166.

16. Mansell, R.; Avgerou, C.; Quah, D. \& Silverstone, R. (editors): The Oxford handbook of information and communication technologies. New York (New York - USA): Oxford University Press Inc. (OUP), 2009. - 752 pp. ISBN 978-0-19-954879-8. doi: 10.1093/oxfordhb/9780199548798. 001.0001.

17. Measuring the Information Society Report 2009: The ICT development index. Geneva (Switzerland): International Telecommunication Union (ITU), 2009. - 96 pp. ISBN 978-92-61-12831-9.

18. Measuring the Information Society Report 2015. Geneva (Switzerland): International Telecommunication Union (ITU), 2015. - 234 pp. ISBN 978-92-61-15791-3.

19. Measuring the Information Society Report 2017. Vol. 1. Geneva (Switzerland): International Telecommunication Union (ITU), 2017. - 154 pp. ISBN 978-92-61-24511-5.

20. Measuring the Information Society Report 2018. Vol. 1. Geneva (Switzerland): International Telecommunication Union (ITU), 2018. - 189 pp. ISBN 978-92-61-27221-0.

21. Moroz, M.: The level of development of the digital economy in Poland and selected European countries: A comparative analysis. Foundations of Management, Vol. 9 (2017), pp. 175-190. ISSN 2300-5661. doi: 10.1515/fman-2017-0014.

22. Nath, H.K. \& Liu, L.: Information and communications technology (ICT) and services trade. Information Economics and Policy, Vol. 41 (December 2017), pp. 81-87. ISSN 0167-6245. doi: 10.1016/j.infoecopol.2017.06.003.

23. Turmanidze, R.; Dašić, P. \& Popkhadze, G.: Analysis of innovation activities in Georgia as a major factor in application of the Industry 4.0 concept. Lecture Notes in Networks and Systems (LNNS), Vol. 233 (2021), pp. 270-277. ISSN 2367-3370 and ISBN 978-3-030-75274-3. doi: 10.1007/978-3-030-75275-0_31.

24. Turmanidze, R.; Dašić, P. \& Popkhadze, G.: Analysis of some socio-economic-technical indicators of Georgia. In: Proceedings of the 9th International Conference "Economics and Management-Based on New Technologies" (EMoNT-2019); Vrnjačka Banja, Serbia; 23-26 June 2019. Vrnjačka Banja: SaTCIP Publisher Ltd., 2019, pp. 1-12. ISBN 978-86-6075-067-1.

25. Turmanidze, R.; Dašić, P. \& Popkhadze, G.: Digital infrastructure in Georgia as a condition for successful application Industry 4.0. International Scientific Journal "Industry 4.0", Vol. 5, Issue 1 (2020), pp. 3-6. ISSN 2534-8582.

26. Turmanidze, R.; Dašić, P. \& Popkhadze, G.: Industry 4.0: New manufacturing philosophy. In: Proceedings of the 18th International Conference "Research and Development in Mechanical Industry" (RaDMI-2018); Vrnjačka Banja, Serbia; 13-16 September 2018. Vrnjačka Banja (Serbia): SaTCIP Publisher Ltd., 2018, pp. 63-74. ISBN 978-86-6075-066-4.

27. Turmanidze, R.; Dašić, P. \& Popkhadze, G.: Statistical analysis of e-government development index (EGDI) of Georgia. Lecture Notes in Networks and Systems (LNNS), Vol. 128 (2020), pp. 930-938. ISSN 2367-3370 and ISBN 978-3-030-46816-3. doi: 10.1007/978-3-030-46817-0_105. 